\title{
Globalization and Cultural Identity of Art Works
}

Abstract: Works of art are properly characterized as cultural objects, as opposed to being merely physical or perceptual objects. As cultural objects, works of art can be embodied in physical objects, but they require properties that physical objects do not necessarily possess, such as being intentionally composed in some artistic medium in a particular historic context informed by ideas, values, and technical skills and means offered by the culture. Works of art retain their identity in important respects, but may also undergo change when transferred from one culture to another. The identity of a work may be enriched and expanded to incorporate features acquired as a result of its being interpreted in a new cultural setting. An expanded and clarified account of culture is required to give a fuller characterization of the cultural properties that comprise works of art and to support the view that cultural identity in some sense transcends a culture of origin. Culture is a multi-phased concept involving at least three related elements. First, there are the particular art cultures consisting of art-making and their attending strategies of interpretation found in the art worlds of various societies. Secondly, the culture of a people consists of the broader societal, political, economic, religious, ideological, and other practices that define a culture. An additional element is world or global culture consisting of the features of art that enable people from diverse cultures to interpret and appreciate art from other cultures. Within

\footnotetext{
${ }^{1}$ Dr. Curtis Carter is a Professor of Philosophy at Marquette University. Email: curtis.carter@marquette.edu.
} 
these frameworks, the identity of art works is open and cumulative, with the result that they continuously acquire new properties over the duration of their existence.

Keywords: art, globalization, cultural identity

UDK 7:005.44

\section{Globalizacija in kulturna identiteta umetniških del}

Izvleček: V nasprotju s tem, da bi bila zgolj fizični ali perceptivni predmet, so umetniška dela primerno okarakterizirana kot kulturni objekti. Kot takšna so lahko umetniška dela utelešena v fizičnih predmetih, a zahtevajo lastnosti, ki jih fizični predmeti nimajo nujno, na primer da so namerno sestavljena v nekem umetniškem mediju $\mathrm{v}$ določenem zgodovinskem kontekstu, ki se napaja z idejami, vrednotami in tehničnimi znanji ter sredstvi, ki jih kultura ponuja. Umetniška dela $\mathrm{v}$ pomembnih pogledih ohranjajo svojo identiteto, a se lahko, ko se prenašajo iz ene kulture v drugo, tudi spreminjajo. Identiteta dela se lahko obogati in razširi, da vključuje lastnosti, ki so pridobljene kot rezultat interpretacije v novem kulturnem okolju. Potrebno je razširjeno in razjasnjeno mnenje o kulturi, da se lahko poda popolnejša karakterizacija kulturnih lastnosti, ki sestavljajo umetniška dela, in se podpre mnenje, da kulturna identiteta v nekem smislu presega izvorno kulturo. Kultura je večfazni koncept, ki vključuje vsaj tri povezane elemente. Najprej so tukaj določene umetniške kulture, sestavljene iz umetnostnega oblikovanja, in njim pripadajoče strategije interpretacije, ki jih je moč najti v umetniških svetovih različnih družb. Drugo je kultura ljudstva, ki sestoji iz širših družbenih, političnih, gospodarskih, verskih, ideoloških in drugih praks, ki določajo neko kulturo. Dodatni element je svetovna ali globalna kultura, sestavljena iz lastnosti umetnosti, ki omogočajo ljudem iz različnih kultur, da interpretirajo in cenijo umetnost iz drugih kultur. Znotraj teh okvirjev je identiteta 
umetniških del odprta in kumulativna, rezultat pa je, da skozi trajanje svojega obstoja kontinuirano pridobivajo nove lastnosti. Ključne besede: umetnost, globalizacija, kulturna identiteta

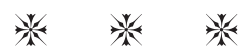

Underlying the question of artistic understanding between the cultures of East and West in the era of globalization is the problem of the identity of works in art in relation to culture. With respect to art and aesthetic values, the problem of cultural identity addresses the question: In what sense might a work of art created in a western culture such as ancient Greece be understood and appreciated in contemporary China? Or in what is the basis for appreciating Andy Warhol's image of a Campbell Soup can created in the United States in the 1960 s when it appears in a Chinese cultural setting? This problem is not simply a matter of developments in the twentieth or twenty-first centuries. For example, in the early nineteenth century the Parthenon Marbles of ancient Greece were welcomed in London in 1800 as the Elgin Marbles when the British Lord Elgin removed them from Athens. The Elgin Marbles were created as part of the Parthenon in fifth century Athens. Since their transfer in 1800 they have resided in the British Museum in London. The question for consideration here is, do the works located in their original settings, respectively in Athens (the Elgin Marbles) and New York (the Campbell Soup Can pictures), have the same cultural identity when viewed in London or in Beijing as the art works had in their original settings? The answer depends in part upon our understanding of cultural identity and our view on how to accommodate the changes resulting from a work transferred to a culture other than its culture of origin and also sustain the identity of the art work. 
I propose to accept in principle the thesis offered by Joseph Margolis and others that works of art are properly characterized as cultural objects, as opposed to being merely physical or perceptual objects. As cultural objects, works of art can be embodied in physical objects, but they require properties that physical objects do not necessarily possess, such as being intentionally composed in some artistic medium in a particular historic context informed by ideas, values, and technical skills and means offered by the culture. Further, it is my intention to argue here for the position that works of art retain their identity in important respects, but may also undergo change when transferred from one culture to another. This means that the identity of a work may be enriched and expanded to incorporate features acquired as a result of its being interpreted in a new cultural setting.

An expanded and clarified account of culture is required to give a fuller characterization of the cultural properties that comprise works of art and to support the view that cultural identity in some sense transcends a culture of origin. My proposal is to think of culture as a multi-phased concept involving at least three related elements. First, there are the particular art cultures consisting of art-making and their attending strategies of interpretation found in the art worlds of various societies. Secondly, the culture of a people consists of the broader societal, political, economic, religious, ideological, and other practices that define a culture. An additional element is world or global culture consisting of the features of art that enable people from diverse cultures to interpret and appreciate art from other cultures. Within these frameworks, the identity of art works is open and cumulative, with the result that they continuously acquire new properties over the duration of their existence.

The plan for developing the remainder of the paper is as follows. I will first undertake a critical review of the notion of culture as it 
appears explicitly or implicitly in the writings of the authors referred to above, and will propose modifications necessary to clarify the cultural nature of works of art. Thirdly, I will consider the question of criteria for judging whether a work retains its identity when it is relocated in another culture, again relating the issue to the cultural factors surrounding the identity of a work of art. The Elgin Marbles and Warhol's Campbell Soup Can paintings will serve as examples to facilitate the discussion. The essay terminates with brief comments on the implications of the discussion here for communication of East-West aesthetic values.

\section{The Elgin Marbles}

Before taking up the broader issues outlined here, it will be useful to consider for a few moments some aspects of the cultural and historical information surrounding the Elgin Marbles. This information will establish the Marbles as works of art and will also provide a concrete reference for the theoretical points that are being considered here.

Nearly 200 years ago in 1800, Lord Elgin sailed to Constantinople to assume the role of ambassador of Great Britain to the Turkish Empire, which then included Athens as well as all of Greece. High on the list of his priorities was the intent to take back to England artists' drawings and casts of the magnificent sculptures and reliefs which had been installed in the Parthenon. Lord Elgin's primary aim was to elevate the standards of artistic practice and taste in England by introducing these works to his countrymen.

The Parthenon had been built on the Acropolis in Athens between 447 and $431 \mathrm{BCE}$ under the direction of the architect, Ictinos, during the administration of Pericles the Athenian ruler and was intended to serve as the Temple of Athena, the patron goddess of Athens. It was part of a program of public works intended to sym- 
bolize the glories of Athens as the center of Greek culture and of political power. The temple itself was built of the finest-grained white marble in the Doric order of Greek architecture, and with extraordinary precision of workmanship, resulting in a perfection of artistic form. The building was adorned by sculptured figures created by or under the direction of the sculptor Phidias. These consisted of groupings of figures carved in the round, representing such mythical events as the birth of Athena and also a legendary contest between Athena and Poseidon. On the outside of the temple, the panels or metopes were carved in high relief with scenes of mythological gods, giants, Lapiths, and centaurs at war. Around the inside was a frieze in low relief of the Panathenaic procession, a major religious ceremony which occurred every four years in the Parthenon. The centerpiece of the Parthenon was the statue called Athena Parthenos. ${ }^{2}$ The figure, designed by Phidias, stood approximately 12 meters high and was adorned with ivory and gold. ${ }^{3}$

By the end of the eighteenth century, the Parthenon was under the reign of the Turkish Empire, and had undergone substantial physical changes in its 2300 year history. The center of the building had been destroyed in 1687, for example, during a siege by the Venetians, and remnants of many parts of the temple were all that remained. During its lifetime, the building had also undergone a variety of uses: including a pagan temple, a Christian Church and a Turkish Mosque.

When Lord Elgin's agents arrived in 1800, the Parthenon was serving various purposes for the Turks occupying the Acropolis. St. Clair details the state of things in his biography of Lord Elgin in these terms:

\footnotetext{
$\overline{2}$ St. Clair, 1967, 52. See also Smith, 1916, 180.

${ }^{3}$ Brommer, 1979, 60.
} 
The Turks living on the Acropolis built their houses, vegetable gardens, and fortifications round about the ruins, or made use of them as it suited their purpose. Inside the Parthenon was a small Mosque, and the spaces between the pillars of the Propylaea were half bricked up to provide a kind of castellation for the guns. Everywhere it was obvious that for years the ruins had been a main source of building materials. ${ }^{4}$

Although Lord Elgin seemed to have had no prior plan to do anything more than to make drawings and casts and, perhaps, to collect a few fragments, the deteriorating condition of the monument, together with the urging of his agents, led to an agreement with Turkish authorities, which resulted in the actual removal of a substantial portion of the principal remaining sculptures to England. At the urging of Elgin's secretary, Reverend Phillip Hunt, Elgin agreed to the drafting of a firman, or official letter of permission. The document was sufficiently vague that it served the English to guarantee the following permissions and protections from the Turkish government:

(1) to enter freely within the walls of the citadel, and to draw and model with plaster the ancient temples there;

(2) to erect scaffolding and to dig where they might wish to discover the ancient foundations;

(3) to take away any sculptures or inscriptions which did not interfere with the works or walls of the citadel. ${ }^{5}$ It is doubtful that the Turks intended to grant permission to actually remove the sculptures, given the fact that Turkish policy had heretofore forbidden the removal of such, particularly from the Parthenon.

\footnotetext{
${ }^{4}$ St. Clair, 51.

${ }^{5}$ Smith, 190.
} 
But Hunt and his colleagues persuaded the chief Turkish offcials to the contrary.

The removal of the Marbles was, at the same time, a controversial event from the beginning. However, the objections and doubts appear to have come from the British, rather than from the Greeks, who were in a state of subjection and decline, or from the Turkish officials, whose actions indicated that their primary interest was in using the Marbles for political or economic benefit. ${ }^{6}$ Lord Byron, who was traveling in Greece at the time the Marbles were transferred to England, denounced Lord Elgin in his satirical poem "Childe Harold's Pilgrimage" as well as in other poems and prose. In "The Curse of Minerva" Byron refers to Elgin as a plunderer who basely stole the treasures of the Parthenon. ${ }^{7}$

\section{Culture, Cultural Objects, and Art}

The interest of philosophers in works of art as cultural objects is not new; rather, it is implicit in the philosophical treatment of art by many philosophers including Plato and Hegel, who both recognized that a work of art is shaped by the state of ideas and artistic practice at the time it is produced. It is unlikely, however, that either of these philosophers would have supposed that all or the most important properties of art could be exhaustively supplied by a particular culture without incorporating an element of the form of beauty or absolute spirit. The incorporation of form or absolute spirit would have been their way of recognizing that the art can be of interest beyond its immediate community.

\footnotetext{
${ }^{6}$ St. Clair, chapters 6, 9.

${ }^{7}$ Lord Byron, 43. See also St. Clair, 187-201.
} 
Over the past two decades, philosophers such as Joseph Margolis, Andrew Harrison, and Arthur Danto have advanced the study of art works as cultural objects. Margolis is a proponent of the notion that works of art are culturally emergent entities embodied in physical objects and that the embodiment of cultural properties is a function of the culture of origin. ${ }^{8}$ Harrison also affirms that culture is the primary factor in bringing works of art into being and establishing their identity. In practice this means that to identify a work of art is to lay down what material events or particulars are to count as instantiating it. ${ }^{9}$ Danto addresses this issue by locating the identity of art works in a matrix which consists of art history and theory operating within the art world at a particular time. ${ }^{10}$ Others who approach cultural identity primarily within the context of interpretation theory include Michael Krausz and Richard Shusterman. Krausz argues that art works are socially constituted entities whose identity is determined by their place within a given practice, sustained by their own aims, rules, and procedures, and sustained by interpretations of informed practitioners. ${ }^{11}$ Shusterman, following Rorty, locates the identity of a work of art in the pragmatically identified propositions, which are provided by the customary ways of talking about such works. ${ }^{12}$ The work of these authors offers a point of departure for examining the effects of a change of culture on the identity of works of art, and I will refer to them from time to time as the discussion proceeds.

Among the philosophers who offer an account of art works as cultural objects, Margolis has developed his views more fully than

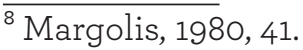

${ }^{9}$ Harrison, 1967-68, 125, 127.

${ }^{10}$ Danto, 1980, 111. See Margolis' critique of Danto's views, in Margolis, 1995, 256-266.

${ }^{11}$ Krausz, 1993, 38, 39.

${ }^{12}$ Shusterman, 1988, 408.
} 
most. In his book Art and Philosophy (1980), he contends that works of art are artifacts that can be identified only in reference to the artistic and appreciative traditions of a given culture. ${ }^{13}$ They share with other cultural objects the condition of being in some sense (nondeductively and nonreductively) linked with physical entities of some sort. Their existence depends upon the culturally informed work of persons who intentionally produce the art works within a specific cultural practice.

According to Margolis, "'cultural' signifies the property of any system in virtue of which certain entities emerge and exist, a system in which both persons and what they may produce- $a$ fortiori works of art-exist or once existed. Such a system is at once rulegoverned, in that what is typically produced is intelligible only in terms of rule-like regularities (traditions, customs, practices, institutions)...."14 It follows that works of art consist of culturally emergent properties intentionally embodied in a physical object according to the rules, customs, and practices of an artistic medium such as sculpture. Among the properties that might be assigned within various practices are representational, expressive, abstract, conceptual, or other stylistic features. The works embody features that would enable an informed audience to grasp their meaning and locate them within a recognizable artistic tradition.

More recently, in his book Interpretation Radical but not Unruly (1995) Margolis emphasizes that emergent properties, in this case aesthetic values, consist of intentional properties which are "social or societal or collective or historical" rather than individual mental or neurological states. ${ }^{15}$ A corollary of this expanded version of cul-

\footnotetext{
${ }^{13}$ Margolis, 1995, 41.

${ }^{14}$ Ibid., 46.

${ }^{15}$ Margolis, 1995, 52.
} 
tural identity is found in Margolis' notion of unicity, a concept that he employs to argue that the identity of a work of art embraces its cumulative history of interpretation over time, in lieu of a fixed nature established at its origin and intended to serve as a referent for all future interpretation. ${ }^{16}$

Margolis' views will serve as a starting point in the development of the three-tiered structure (art culture, culture of a people, and world or global culture) necessary to provide an account of cultural identity for works of art that extends beyond the culture of origin and addresses the continuing issue of identity for works of art originating in one culture and subsequently being relocated in another. The account of cultural identity given in Art and Philosophy, emphasizing a tradition of art production and interpretation, fits the notion of an art culture, which provides the rules of a practice necessary to account for the cultural identity of art. Art culture represents the world of the practitioners and includes artists, critics, and institutions responsible for training, interpreting, and maintaining the traditions and developing new practices as the culture evolves. It consists of a specialized culture focusing on the aesthetic, stylistic and technological aspects of production. Art cultures do not exist independently of the wider culture of which they are a part. In many instances, a plurality of art cultures may exist as part of a whole culture, each with its own important links to the larger culture. In modern societies it is now common for fine art, folk, and popular art cultures to exist simultaneously. Similarly a plurality of fine art, folk, or popular art cultures may exist within a single larger culture.

Applying this concept to the Elgin Marbles, one might say that the Parthenon Marbles were the product of a particular artistic practice under the direction of Phidias and his artist collaborators in

$\overline{{ }^{16} \text { Ibid., } 33-35,46 .}$ 
Athens of the fifth century BCE, which embodied them with the figurative, naturalistic concepts of a style of representational art.

There is merit in considering this aspect of the identity of art works. It is favored by certain approaches to art history because it lends understanding to the origins of the work and the practices surrounding its production. In claiming that cultural properties are to be understood as rule governed regularities of a particular tradition of artistic production and interpretation, Margolis also favors a narrower rather than a broader context in which to discuss the "rules" governing the identity of works of art, such as is provided by an art culture. ${ }^{17}$ However challenging it might be to come up with a coherent set of rules governing an art practice for a particular art culture, it would be even more difficult to do so for the culture of a people.

Nevertheless, there are serious problems with limiting our discussion of cultural identity to a particular art culture. Such a limited view would isolate what is occurring in the larger community (culture of a people). Moreover, a history of art which deals only with the art culture surrounding the origins of a work of art in an art culture would necessarily exclude a significant portion of the life of the art work which follows from its interpretations and uses in history. Hence the specialized art culture in which a work of art is produced does not account for all of the cultural properties that are important, namely those which derive from the larger culture of which the art culture may be a part. Most importantly, 'art culture' does not adequately explain how a work of art sustains a continuous identity when it is removed from its culture of origin and relocated within another culture.

Hence it is necessary to introduce at this time the notion of the culture of a people to broaden the context for considering the cultural

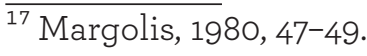


identity of art. This sense of culture might include myth, language, philosophy, recreation, and technology, as well as the institutions of politics, economics, law, and education. A culture in this sense covers formal and informal ways of behavior, including the thinking, feeling, and doing expressed through day to day involvement in the various practices and institutions. Art practices of particular cultures function within, and interactively, with these other aspects of the culture of a people. Therefore it is necessary to take account of the interactive influences from the larger culture on the practices of art when contemplating the cultural identity of works of art.

In traditional tribal societies works of art are closely linked with community life, where they incorporate the values of the community and also participate in the processes of social integration. Sculptures are used in certain African communities, for instance, to symbolize harmony among the members of the community and to invoke ancestor presence as a means of establishing continuity between past and present members of the community. Mythical images incorporated symbolically into tribal art may also relate to the cycle of life and death. ${ }^{18}$

With respect to the Parthenon Marbles, the primary reason for their coming into being lies beyond the particular art culture that produced them. As we have seen earlier, it was the desire of Pericles and his fellow citizens to produce a monument that would embody the achievements of Athens and symbolize for all the world its superior political, material, and spiritual achievements. This aim led Pericles and his followers to appropriate their own treasures, often coupled with the treasures of their unwilling allies to create a culture with unsurpassed art and architecture at its very center. Even

\footnotetext{
$\overline{{ }^{18} \text { Botombele, }} 1976,22-23$. See also Bahoken, 1976, 14. World Conference on Cultural Policies: Problems and Prospects, 1982, 31.
} 
the ruins of Ancient Athens still command the awe of Greeks and generations world wide, and have generated unending debate among critics and historians particularly over the significance of the Parthenon Marbles. This debate and the attending historical events have extended their significance far beyond the particular art culture of their origin. As Melinda Mercuri's impassioned remarks imply, the cultural identity of works of art is integrally linked to the culture of a people:

"We are talking about the unity of a unique moment which is part of the culture and democracy of Greece. The Marbles are part of a monument to Greek identity ... our roots, our continuity, our soul."19

The extension of cultural identity of art works to include the culture of a people would appear to go beyond Margolis' initial formulation of cultural identity in Art and Philosophy, which was essentially linked to the art culture of origin. However, Margolis' more recent version of cultural identity found in Interpretation Radical But Not Unruly, with an emphasis on the societal, historical, open-ended sense of cultural identity, appears to be, in principle, consistent with recognition of the broader culture of a people as a necessary component of the identity of art works. There, Margolis notes that the intentional, which is the agent of embodying cultural properties in physical forms, has already internalized “... the Lebensformen of a particular society." 20

The purpose of drawing attention to the larger scope of culture found in the culture of a people is to point out that at least some of the important cultural properties embodied in works of art are a re-

\footnotetext{
$\overline{19}$ Touhy, Milwaukee Journal, June 27, 1983.

${ }^{20}$ Margolis, 1995, 52.
} 
sult of arts connections to the religious, mythical, political, economic and other values and activities that are important to the general culture of a people. This notion expands our basis for understanding the cultural identity of works operating within a particular local culture. Yet it does not account for the identity of works in a new culture, such as the case of the transfer of the Parthenon Marbles to England.

The relocation of the Marbles (now referred to as the Elgin Marbles, after Lord Elgin who arranged for the entry of the Marbles into England) offers insight into the process by which a work of art from one local culture enters into another local culture, and the implications of such changes for the cultural identity of the work. The first of the Marbles arrived in England in 1806. The critical and interpretive responses of the British art world and the public at the time of their arrival are well documented. Their arrival generated substantial enthusiasm among England's artists and critics and the public. The responses of the British art culture were immediate and intense. Critics debated the specific properties of the Marbles in a context of ideas about classical art based on their familiarity with such work as the "Apollo Belvedere", located in the Vatican collection in Rome, and the "Venus de Milo", housed at the Louvre in Paris. The British art world was startled by the contrast between the vital, life-like properties embodied in the Marbles and the more academic, ethereal properties of the Apollo and the Venus. At that time, the critics were unaware that these works were Roman copies or Hellenistic statues rather than classic works of the fifth century.

Leading English artists of the time, such as Benjamin West, Thomas Lawrence, and J. M. W. Turner, immediately acclaimed the significance of the Marbles, and may have been influenced by their imagery. "There is in them," said Lawrence, "an union of fine composition and very grand form, with a more true and natural expression of the effect of action upon the human frame than there is in 
the Apollo or any of the other most celebrated statues." ${ }^{21}$ On the other hand, critics such as William Hazlitt brought to the Marbles a new set of interpretive properties by presenting them in the light of their own interpretive theories. Hazlitt applied a variant of British Romanticism to the Marbles in these brief excerpts:

This is the great excellence of the Elgin Marbles, that they do not seem to be the outer surface of a hard and immovable block of Marble, but to be actualized by an internal machinery, and composed of the same soft and flexible materials as the human body. ${ }^{22}$

Their "amazing vitality and "life-like appearances" led Hazlitt to extend further his attribution of the qualities of nature to the Marbles.

Nothing remains of them but their style; but that is everything, for it is the style of nature. Art is the imitation of nature; and the Elgin Marbles are in their essence and their perfection casts from nature-from fine nature it is true, but from real, living, moving nature, from objects in nature, answering to an idea in the artist's mind. ... ${ }^{23}$

Ennio Quirino Visconti, director of the Capitoline Museum at Rome and later director of the Louvre in Paris, and Antonio Canova, a leading European sculptor and critic, visited the Elgin collection in London and responded with high enthusiasm concerning the authenticity and artistic importance of the Marbles. Their views brought international confirmation of the favorable responses to the marbles from the English art world.

${ }^{21}$ Report from the Select Committee of the House on the Earl of Elgin's Collection of Sculptured Marbles. Also cited in St. Clair, 254.

${ }^{22}$ Hazlitt, 1822, 154.

${ }^{23}$ Hazlitt, 1934, 100 
There were also less favorable critical interpretations applied to the Marbles. Richard Paine Knight, a leading English critic, was steadfastly unenthusiastic about the significance of the Elgin Marbles. He maintained that they were in fact from the later period of Hadrian, and in such poor condition that they were of relatively secondary interest. His cryptic remarks convey his sentiments: "You have lost your labor, my Lord Elgin; your Marbles are overratedthery are not Greek, they are Roman, of the time of Hadrian, when he restored the Parthenon .... ${ }^{24}$ But Knight's interpretation failed to carry the day and did not significantly affect critical or popular understanding of the Marbles in England.

The responses to the Marbles within the British public were substantial. Debates in Parliament over the purchase of the Marbles, as well as questions about their artistic merit and ownership had brought the matter of their role in English culture to wide public attention. Additional interest and awareness had followed public exhibitions of the Marbles beginning soon after their arrival in England. The result of the processes of incorporating the Marbles into the art culture and the culture of the British people was to firmly establish a place and a meaning for the Marbles in their new cultural home. The principal change from the Greek understanding of the Marbles was the substitution of British for Greek cultural interests. The British interpreted the Marbles in reference to their own national interests, viewing them as "proud trophies" of British prestige. ${ }^{25}$ With respect to their artistic status, the Marbles were widely admired as works of fine art which the British found no difficulty placing in their most prestigious showcase at the British Museum. Parenthetically, it is interesting to note that the issues of national

\footnotetext{
$\overline{{ }^{24} \text { Messman, } 1973,71 .}$

${ }^{25}$ Smith, 1916, 35.
} 
honor and their significance as works of art were important factors in the deliberations of the select committee and in parliamentary debates over the legitimacy of their official acquisition by the British nation.

In summary, the strong reception of the Marbles in England as works of art suggests that they did retain their cultural identity as works of art through the change of cultures. The closing words of an editorial exchange in 1941, between the editors of the Burlington and the Connoisseur art journals over the return of the Marbles to Greece, attests to the extent to which the Marbles have been assimilated into British culture: "What we have we will hold." 6

Having shown by example that such cultural transfers do exist and that the works continue to have meaning outside their cultures of origin, it remains to account for this phenomenon. First, it is necessary to look further into the question of identity for the transplanted Marbles. Let us begin by inquiring into the relationship of the "Elgin Marbles" located in the British Museum to the "Parthenon Marbles" that formerly resided at the Parthenon in Athens. Here it is necessary to ask, do the two terms refer to the same work of art? Throughout this disucssion, the Marbles have been represented as composite objects; consisting of a set of physical objects (pieces of marble) embodied with intentional properties (their form given by the artist operating within various levels of culture), as well as interpretive properties acquired throughout their life.

Suppose we limit the discussion for a moment to the culturally embodied physical object. Among the accepted criteria for the identity of culturally embodied physical objects is identity of parts and spatio-temporal continuity. If we mean, do the terms 'Elgin Marbles' and 'Parthenon Marbles' refer to the same configuration of natural

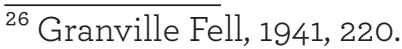


marble and technical and stylistic markings, the answer would be a qualified yes. The qualification derives from the fact that the Elgin Marbles were initially attached to the temple on the Parthenon as part of a larger work, and from possible physical alterations resulting from faulty cleaning, or aging over time. Nevertheless, the major parts of the Marbles have remained continuous throughout their history, and their form is intact. For all technical and formal purposes, they retain the same numerical identity.

On another level, the situation here recalls Frege's classical formulation of the problem of identity of meanings. Gottlieb Frege argued that identity is to be interpreted as a relation between the names of objects rather than as relations between objects themselves. I take this to mean that for identical objects the descriptions that apply to one will apply to the other. Applying this notion to the Elgin Marbles, it follows that the cognitive sense of Elgin Marbles will vary in some respects from the "sense" of Parthenon Marbles, even though they refer to the same numerical entity. The difference follows from the fact that "Parthenon Marbles" refers to the Marbles as seen from the Greek perspective, whereas "Elgin Marbles" encompasses the British perspective at a given moment in their respective histories.

Thus far, our analysis suggests that the cultural identity of the Marbles incorporates the interpretive properties derived from an historical understanding of their culture of origin and, additionally, those properties which derive from its life in the new culture. One way to view the matter, as I do, is to adopt the view that the cultural identity of a work of art encompasses its entire history of production and interpretation. From my perspective, all of the interpretive properties that have been associated with the Marbles, including their Greek and English cultural histories, and even the interpretations brought by visitors from other cultures, become a part of their evolving identity. The cultural identity of the work is necessarily 
open ended in the sense that it includes past, present, and future properties. Changes that occur in the properties of a work can be additive as when the work is interpreted in a fresh light, or selective when taking on the interests of particular interpreters. The British may at a particular time choose to add to, ignore, or suppress the special interpretive properties which the Greeks may have invested in the Marbles, or vice versa, but this action does not alter the fact that the respective properties are a part of any complete account of the identity of the Marbles. It would not be necessary, however, that any one person contemplating the Marbles should have in mind all of the possible interpretive properties, only a sufficiently rich sampling grounded in first hand experience and augmented by critical discussions as required by the viewer's purposes. An art historical comprehension or a critical assessment of the works would obviously call for perusal of a greater range of interpretive properties than would be sufficient for a casual tourist's needs.

This requires the acknowledgment that some of the properties contributing to the cultural identity of works of art may originate outside their culture of origin, a view contrary to Margolis' initial view. This would imply also that the understanding of art works extends beyond particular cultural boundaries, and calls for an account of their appreciation and understanding when viewed outside a particular culture of origin. As far as I can determine, Margolis' view of cultural identity does not explain how a work can be understood outside its culture of origin, although he does not deny that works of art can have meaning beyond their cultures of origin. Without some common ground among the interpreters extending beyond a particular local culture, an historical understanding of cultural identity that embraces, in principle, the entire range of activities surrounding the work is insufficient to explain how a work can have meaning outside its culture of origin. 
To remedy this deficiency, I would introduce the notion of world culture or global culture as providing a level of understanding that extends beyond the scope of particular local cultures or culture of a people. The problem remains how to explain that the cultural identity of a work produced in one of these cultures transfers to another and retains a continuous identity sufficient to provide meaningful interpretation and understanding. There are two possible answers. First, the possibility that the works are embodied with expressive, formal, or other world cultural properties that contribute to their being understood at some level by persons, irrespective of variations in the rules and means governing local cultural practices. Secondly, this would require of persons that they possess, or are able to acquire through learning, the necessary attitudes and aptitudes for transcending particular cultural languages, including those of the arts. Cases like the successful relocation of the Elgin Marbles in England demonstrate that art works do successfully transfer, and the entire world system of museums is predicated on the premise that such cross cultural understanding is possible.

Many philosophers have alluded to the necessity of some broader frame for human understanding which would extend beyond local cultures. An ancient philosopher such as Plato or Aristotle might have centered the discussion of global properties in terms like beauty, truth, and goodness. But for us these terms do not say as much. With the possible exception of beauty, they have lost their richness and are afloat in a quest for clarity and specificity through philosophical analysis.

Hegel, perhaps, understood better than most the importance of world culture when he linked art to the realm of spirit. ${ }^{27}$ Hegel wisely did not provide any strict rules for producing or identifying

${ }^{27}$ Hegel, 1979, 413-414. Also, Hegel, 1975, 56-58. See Carter, 1986, 239-256. 
the properties of art that might be used to sustain universal interest from one culture to another, a task far more demanding than giving rules to a particular art culture, or to the art of a people. Instead, he relied on a typological outline marking the particular stages in the world historical development of art as an important manifestation of the disclosure of world spirit or absolute spirit. In his scheme, there is no break between developments in particular historical epochs and the world spirit. Individuals, civilizations, and the absolute all participate in a common milieu, which at least in principle might accommodate communication between cultures and allow for transcultural understanding.

Karl Popper alludes to a possible structure for locating the foundations for transcultural understanding of art works in his discussion of objective musical work, in conjunction with his "world 3," which he characterized as consisting of objective contents of thought, derived from actions in worlds 1 and 2; or the physical and the subjective respectively. ${ }^{28}$ Such objective entities would represent the results of solutions to problems that arise in particular historical conditions, but transcend the limits of local cultures, thus suggesting another possibility for transcending the bounds of local cultures.

Gadamer's hermeneutic approach to the understanding of cultural works relies on a "fusion of the horizons" that melds an understanding of the historic past with our own comprehension of it. This process includes a universal or classical perspective to facilitate communication across the boundaries of particular historical cultures. Perhaps this universal element of human communication could be useful for the purpose of deciphering the meaning of an art work from another culture. He also holds the view that "the very

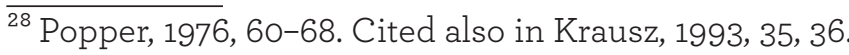


fact of human communication signifies the universality of human nature."29

I do not point out these views here for critical examination or commendation. Rather, it is to note that an appeal to transcultural conditions of human communication, as a means of accounting for crosscultural understanding, is not without its serious proponents.

Among recent work on this problem of cultural identity, Margolis' account of "radical history," based on a critical synthesis of analytic, hermeneutic, and poststructural developments in twentieth century philosophy, offers an alternative to traditional views. Margolis eschews all claims to changeless universals or invariantly structured cultural identities for art works, proposing instead to replace these with narrative devices or socially shared histories of interpretation. ${ }^{30}$ The historical, in this instance, incorporates the actual events as historicized over time, and most importantly, the experience of the interpreter at a given moment in time. Applying this notion to the problem of cultural identity for art works means that identity would be established at any given moment by consulting an informed societal concensus "grounded in the habits of life" of the community. This tactic might well be suited for identity questions within a particular local culture, but it remains unclear how Margolis' latest proposal would account for the cultural identiy of art works outside the particular society or on a global basis.

There is one possible answer. That would be to adopt a global understanding of community, in which the boundaries of all local communities are dissolved into one world community. This is in some sense what Hegel has in mind as an ultimate strategy, and

\footnotetext{
${ }^{29}$ Gadamer, 1975, 337. See also Gadamer, 1976. Margolis offers an extensive critique of Gadamer throughout Interpretation Radical But Not Unruly. See especially 48-52; 76-81.

${ }^{30}$ Margolis, 1995, 52.
} 
perhaps Popper and Gadamer in their respective ways as well. I am not at all certain that this is what Margolis has in mind, but otherwise his insistence on restricting the exploration of cultural identity to the limits of local cultures could not adequately address the larger issues of cultural identity, that is, how to account for cultural identity beyond local cultures.

Clearly the struggle between local cultures and global culture has become one of the major issues of the late twentieth century. We cannot hope to resolve all of the issues of political and economic dominance that this struggle entails. But it is possible that one small step toward global understanding is to continue exploring ways to make the art works of a particular culture accessible to the people of other cultures.

In this analysis, I have attempted to identify three aspects of culture that enter into the cultural identity of works of art. First, art culture, which supplies the technical and formal elements of art production. Secondly, the culture of a people, which links the art work to the various other components that form a particular community. The third is the idea of a world culture, which addresses the fact that the interest in art works is not necessarily limited to the particular culture in which they emerge. Each of these levels of culture respectively contributes to cultural identity.

The use of the Elgin Marbles as a case study has, perhaps, been helpful in making clear some of the issues that are involved in questions concerning cultural identity. With respect to the historic situation surrounding the Marbles, I have shown that the Elgin Marbles share an identity with the Parthenon Marbles, an identity which was reconstituted in England during the early nineteenth century, and which is reconstituted from time to time as a focus of the debates over their artistic significance and the question whether they rightly belong in England or in Greece. Their identity must be 
viewed as consisting of their on-going cumulative history, which begins with their production in fifth century Athens and embraces their new life in England. Like all truly great works of art, the Marbles do not belong to a particular people, but are to be shared in a broader world culture. Great art speaks from the viewpoint of an encompassed humanity, albeit produced through the seemingly abridged elements found in our various local cultures. ${ }^{31}$

Bringing the focus of the discussion closer to our time, aesthetic values have undergone radical changes as western art has undergone substantial changes from modern art to pop art, leading to the emergence of a highly pluralistic art culture. The changes have been so radical that it is difficult for many people to comprehend, let alone appreciate some of the new developments. The radical changes in pictorial composition introduced by Picasso's cubism, the pop art paintings of Warhol in the 1960s, and the post-modern aesthetics of late twentieth century media arts are but a few markers of changes in the arts and aesthetic values. Who would have thought that any one could think of selecting a commercial commodity, such as a soup can, as a subject for art? And yet Warhol catapulted to world wide fame by introducing into his work symbolism

\footnotetext{
${ }^{31}$ As for the present dispute between Greece and England, there is no support in this analysis of the identity of the Marbles for the nationalistic claims of either country. There is no question that the role of England in preserving these works has been immensely important in their past preservation. From this it does not, however, follow automatically that their claim is forever. The issue must be decided on other grounds: that is, in the best interest of preservation and the proper display of the works for the world's appreciation and understanding. The decision is best left to the responsible members of the world arts community who are, one hopes, able to distinguish national interest from more fundamental issues of art conservation and the interpretation of these important works for the world community.
} 
drawn from the everyday experiences that caught the spirit of midtwentieth century America. In this work he followed the imagery of mass advertising, focusing on everyday objects that were understandable to the masses, and also caught the attention of the art world. At first Warhol's art might seem the very antithesis of what has been traditional in art, the images that are removed from everyday life and focused on more high minded matters. What, we may ask, would happen to this art in China today? Would it garner understanding and appreciation? What values does it carry? How would it be changed by being placed in the culture of contemporary China? Given that there is already in place a Chinese pop art movement, with its own culturally specific symbols and aesthetic values, it might come to be appreciated. If the thesis offered here is viable, the Soup Can painting would retain its original aesthetic values to be shared with a different culture, but Chinese interpretations would expand upon the meaning as the work became acclimated to a new cultural setting.

In order to bring the topic of the cultural identity of art works closer to home, it is useful to consider how the dominance of globalization in contemporary world cultures has affected our understanding of cultural identity. There is no time here to develop this issue, but perhaps an example will serve to point in a direction for further research. As a closing reference, I will briefly consider cultural identity as it applies to contemporary artists practicing in China and elsewhere today. Chinese contemporary artists in particular must struggle with the question of how their work relates to a near 5000 year tradition of aesthetics and art practices, as they experiment with and modify Chinese art and culture of the past. The central problem Chinese contemporary artists face is how to build upon their Chinese cultural heritage and also connect to new developments of contemporary life in China and throughout the 
world. It is on the mind of every serious contemporary Chinese artist how to remain connected to their Chinese roots while creating art that would be appreciated in a changing world, where East and West are drawn ever closer. Addressing these changes is not a question of Chinese art versus western art. Rather, the practice of art in a global context has become a matter of enabling individual artists to create by using the ideas and visual forms irrespective of their particular cultural origin, while establishing relevance to contemporary Chinese culture. This means that there is at the artist's disposal an evolving universal vocabulary of artistic means, contributed over time from the practices of artists working in many cultures throughout the world. Creating art today thus requires considering exactly such a universal visual language. The solution does not lie in creating a new "International Style" reminiscent of the Euro centered International Style, grounded in formalism and proposed as the norm for western architecture of the modernist era. Rather, the situation invites artists to continue to develop new ideas for art, incorporating their cultural histories and those of others.

\section{Conclusions}

What can be learned from this analysis about the question of communication of aesthetic values between the respective cultures of the East and the West? First, this analysis provides a framework for understanding culture in terms of its multiple dimensions. These dimensions include the idea of a culture based on the aesthetic values associated with a particular art practice (for example classical representational sculpture or modern pop art painting), national cultures such as ancient Greece or contemporary China, and global world culture in which all persons participate by virtue of their common humanity. In this multiple framework, art has the possibility of serving as an important means for communicating and understand- 
ing cultural values. Understanding the art of another culture is thus one means of establishing communication among the different cultures world wide. Art, apart from its culturally specific means, is also grounded in common human capacities, such as the ability to recognize and value creative expressions of ideas and feelings.

Secondly, the analysis offered here recognizes that the identity of works of art is not static or fixed. As a work of art enters into another culture, its meaning may change as it is seen in a different cultural framework, allowing for new interpretations with reference to the values of a new environment. Hence a sculpture from ancient Greece, when seen in London or Beijing, or a Warhol Campbell Soup painting in a cultural setting in Asia, may bring an opportunity for communication of values. Finally, as artists from China increasingly attempt to incorporate elements drawn from the visual cultures of both East and West, discussions concerning the cultural identity of works of art will have to expand to take these changes into account.

\section{Bibliography}

BAHOKEN, J. C. (1976): Cultural Policy in the United Republic of Cameroon, UNESCO, Paris.

BOTOMBELE, B. E. (1976): Cultural Policy in the Republic of Zaire, UNESCO, Paris.

BROMMER, F. (1979): The Sculptures of the Parthenon, Thames and Hudson, London.

CARTER, C. L. (1986): "Hegel and Whitehead on Aesthetic Symbols," in Hegel and Whitehead, edited by George R. Lucas, Jr., State University of New York Press, Albany, 239-256.

DANTO, A. (1980): The Transformation of the Commonplace, Harvard University Press, Cambridge, Massachusetts. 
GADAMER, H. G. (1976): "The Universality of the Hermeneutical Problem," Philosophical Hermeneutics, trans. David E. Linge, University of California Press, Berkeley, Los Angeles, London.

GADAMER, H. G. (1975): Truth and Method, trans. Garrett Barden and John Cummings, Seabury Press, New York.

GRANVILLE FELL, H. (1941): "Hands Off the Elgin Marbles," The Connoisseur, 107.

HARRISON, A. (1967-1968): "Works of Art and Other Cultural Objects," Proceedings of the Aristotelian Society, 68, 105-125.

HAZLITT, W. (1822): London Magazine, 154.

HAZLITT, W. (1934): The Complete Works of William Hazlitt, ed. P. P. Howe, v. 18.

HEGEL, G. W. F. (1975): Lectures on the Philosophy of World History, translated by H. B. Nisbet, Cambridge University Press, MANJKA KRAJ.

HEGEL, G. W. F. (1979): The Philosophy of Spirit, trans. M. J. Petry, Hegel's Philosophy of Subjective Spirit, 3 Vols, Riedel, Dordrecht, II: 413-414.

KRAUSZ, M. (1993): Rightness and Reasons, Cornell University Press, Ithaca and London.

LORD BYRON (1922): “Childe Harold's Pilgrimage,” Canto II. MARGOLIS, J. (1980): Art and Philosophy, Humanities Press, Atlantic Highlands, New Jersey.

MARGOLIS, J. (1995): Interpretation Radical but Not Unruly: The New Puzzle of the Arts and History, University of California Press, Berkeley, Los Angeles, London.

MESSMAN, F. J. (1973): "Richard Payne Knight and the Elgin Marbles Controversy," British Journal of Aesthetics, 13(1), 69-75.

POPPER, K. (1976): Unended Quest: An Intellectual Biography, Open Court Press, LaSalle, IL. 
SHUSTERMAN, R. (1988): "Interpretation, Intention, and Truth," Journal of Aesthetics and Art Criticism, XLVI no. 3, manjkajo strani. SMITH, A. H. (1916): "Lord Elgin and His Collection," The Journal of Hellenic Studies, 36, 163.

ST. CLAIR, W. (1967): Lord Elgin and the Marbles, Oxford University Press, London.

World Conference on Cultural Policies: Problems and Prospects (1982), UNESCO, Paris. 